\title{
FORMING LINGUISTIC AND COMMUNICATIVE COMPETENCES IN TWINS WITH DELAYED SPEECH DEVELOPMENT AT THE AGE 0 TO 4
}

The ability to shape and develop linguistic competence is inseparably connected with the pre-natal period in the child's life. The proper structure of the brain, peripheral nervous system, speech organs, the organs of hearing as well as functional architecture of neural network determines the genetic functioning of the speech acquisition mechanism. This is so called tacit knowledge, connected with the use of a language system, which, according to Chomsky, enables children to master the grammar rules of their mother tongue over the next months and years. ${ }^{1}$ The foetus, listening to the sound, intonation and prosodic features of language of the mother's voice coming from the outside of the womb, starts to shape and acquire communicative competence. The competence, in the post-natal period, will be continued in the form of a "dialogue" of string syllables with the nearest caregivers. Over the next months the child will be shaping and continuously developing its communicative and linguistic competence while learning the rules and principles of communication in social interactions.

The problem appears in the situation when there are complications in the pre-natal period and the pregnancy ends prematurely, failing to provide the chance for full development of structures responsible for the forming of linguistic and communicative competence. The purpose of this paper is to present how the linguistic and communicative competence is formed in the twins born in the 29th week of pregnancy and to compare their inter-subject differences in speech development. Currently the

* Magdalena Czajkowska, mgr fizjoterapii/logopeda, Uniwersytet Szczeciński, Wydział Filologiczny. Zainteresowania naukowe: zaburzenia rozwojowe w obrębie okresu prewerbalnego i dysfunkcje rozwoju mowy u niemowląt i dzieci; czajkowskamagdalena@interia.pl

1 Ewa Czaplewska, „Diagnoza zaburzeń rozwoju artykulacji”, in: Diagnoza logopedyczna, ed. Ewa Czaplewska, Stanisław Milewski (Gdańsk: Gdańskie Wydawnictwo Psychologiczne, 2012), 75. 
twins are 4.5 years old, and are under the care of a specialized early intervention health care facility. Their speech development compared to the children of the same age is much delayed; therefore they undergo comprehensive speech therapy and psychological therapy.

\section{Linguistic behaviour of a 4-year-old child}

Children over the age of 4 who are correctly developing their linguistic behaviour master the skills acquired at an earlier age. Therefore their vocabulary is expanded, their phonetic and phonological system and syntax is perfected. They start to include in their utterances some words and phrases with emotional content, such as really?!, that's incredible!, wow! - often heard from adults or fairy tale characters. ${ }^{2}$ The children develop their narrative skills, most often in the form of a one-sentence utterances, acquire the skill of naming simple cause and effect relationships or time relationships, which enables them to connect the events and express them linguistically. ${ }^{3}$ A 4-year-old answers the majority of basic questions (such as What is your name?, Where do you live?, Where did your mother go?. A 4-year-old child learns to use prepositional phrases, which are used to express spatial relationships (such as on, to, in), causal relationships or time relationships (such as after dinner, after lunch, after a walk). ${ }^{4}$ Incessant questions from the child about his/her surroundings are typical of this period. The answers from an adult provide potential knowledge of the world and provide linguistic and cultural models, new vocabulary and thus affect the possibility of forming the communicative competence of the child during social interactions. ${ }^{5}$ In terms of articulation, the phones $-s,-z,-c,-d z$ are already fixed and a 4-year-old child should not replace them with the phones $-\dot{s},-\dot{z},-\dot{c},-d \dot{z}$. The phone $-r$ may appear. The lack of articulation of this phone for this age is not an abnormality, however, according to Kaczmarek, it is usually mastered at the end of the fourth year. ${ }^{6}$ The phones $-s z,-\dot{z},-c z,-d \dot{z}$ are still replaced with phones $-s,-z,-c,-d z$ or $-\dot{s},-\dot{z},-\dot{c},-d z^{7}$ (physi-

2 Jagoda Cieszyńska, Marta Korendo, Wczesna interwencja terapeutyczna (Kraków: Wydawnictwo Edukacyjne, 2007), 182-183.

3 Cieszyńska, Korendo, Wczesna interwencja terapeutyczna, 183.

4 Maria Kielar-Turska, „Rozwój sprawności językowych i komunikacyjnych”, in: Diagnoza logopedyczna, ed. Ewa Czaplewska, Stanisław Milewski (Gdańsk: Gdańskie Wydawnictwo Psychologiczne, 2012), 43.

5 Cieszyńska, Korendo, Wczesna interwencja terapeutyczna, 184.

6 Leon Kaczmarek, Nasze dziecko uczy się mowy (Lublin: Wydawnictwo Lubelskie, 1977), 69.

7 Explanations: $s z$ - voiceless retroflex sibilant; $\dot{z}$ - voiced retroflex sibilant; $c$ - voiceless alveolar affricate; $c z$ - voiceless retroflex affricate; $d \dot{z}$ - voiced retroflex affricate; $d z$ - voiced alveolar affricate; $d \dot{z}$ - voiced alveolo-palatal affricate; $s$ - voiceless alveolo-palatal sibilant; $\dot{z}$ - voiced alveolo-palatal sibilant; $\dot{c}$ - voiceless alveolo-palatal affricate. 
ological lisp), and the group of consonants are simplified. ${ }^{8} \mathrm{~A}$ child over the age of four smoothly and willingly interacts with his peers and adults, developing cognitive functions, learning the rules and standards of the society in which he/she grows. Such a harmonious development of linguistic and communicative competence corresponds to the proper biological development. The situation of language acquisition is strikingly different in the case of abnormalities such as pre-term birth and complications connected with the immaturity of the central nervous system.

\section{Linguistic and communicative competence of twins with delayed speech development - empirical research}

The twins are under the therapeutic care of a non-public health facility in Silesia, Poland. The facility provides early therapeutic intervention as well as motoric, speech and psychological rehabilitation. The author of this text is a member of the therapeutic staff in this facility. To date the results of the boys' speech development have not been discussed so widely.

\subsection{Twin 1}

\subsubsection{Case description}

The first boy was born in $29 \mathrm{Hbd}$ (week of pregnancy) with birth weight $600 \mathrm{~g}$, and scored 6 in Apgar scale. ${ }^{9}$ In the first 24 hours the child suffered from a brain haemorrhage with anoxia; the baby spent 2.5 months in a neonatal incubator. In the neonatal ward the boy was fed through a naso-gastric tube. Attempts to breastfeed were unsuccessful. On the day on which the baby was discharged from the hospital, a special feeding bottle teat for premature babies was selected through which the baby was fed. The hearing test revealed no abnormalities.

Due to a direct correlation between the ability to ingest food (sucking, swallowing, biting, chewing) and the development of articulation functions - the details about diagnostics and therapeutic procedure are intertwined in the case description. For speech development - secondary skills - correct development of primary abilities is necessary, which are the matrix of movements for lips, tongue, jaw, breathing and phonatory models in the execution of first syllables and words..$^{10}$ In parallel with psy-

8 Genowefa Demel, Minimum logopedyczne nauczyciela przedszkola (Warszawa: Wydawnictwo Szkolne i Pedagogiczne, 1987), 12.

9 Maximum score for a child is 10 .

10 Elżbieta Stecko, Zaburzenia mowy dzieci - wczesne rozpoznawanie i postepowanie logopedyczne (Warszawa: Wydawnictwa Uniwersytetu Warszawskiego, 1996), 17-19. 
chomotor development and perfection of gross ${ }^{11}$ and fine motor skills ${ }^{12}$ the child's linguistic system is being formed.

The first assessment in terms of neurology and speech therapy took place after 7 months (the corrected age ${ }^{13}$ of the baby -4 months). In the subsequent regular tests of feeding skills it was noted that the baby tolerated a touch on his face, sensory feelings were at the correct level of tolerance; the boy steadily sucked on his feeding bottle teat; the boy had not yet been spoon-fed. When the baby was seven months old, intensive orofacial stimulation began - putting fingers in his mouth. Spoon-feeding began; the boy correctly took his food, which may point to a proper neuromotoric control of the articulators, mostly lips. When the boy was 10 months old, he could not handle any lumpy food; semiliquid consistency of food induced vomiting reflex. Orofacial area reflexes (sucking, swallowing, chewing, biting) were integrated in the 11th month of life. The boy still did not accept any lumpy food. In the 13th month of life there was still no tolerance to lumpy food; oversensitivity to touch in the area of lips and oral mucosa was developing and orofacial stimulation was intensified. The program of neurological and speech therapy started to include tactual stimulation of the baby's face and hands (using various textures - rough, smooth, a touch by a feather, terrycloth), olfactory stimulation (smell of coffee, cinnamon, vanilla), taste stimulation (sweet, salty, sour taste). In the first stage of simulation the baby's reaction was crying. Over the next weeks the baby adapted to the aforementioned stimulation and to the introduced therapeutic speech massage. In the 15 and 16th months of life there were still distinct difficulties in bottle feeding and spoon feeding. An excessive vomiting reflex appeared. Attempts to introduce spoon up to the alveolar ridge incured vomiting reflex. The speech therapist introduced chewing training, continued with the tactual simulation of the face and oral mucosa, olfactory and taste stimulations, adding more smells and tastes. As a result of introduced chewing training, the vomiting reflex started to back up behind the alveolar ridge to the palate, as a result of which it was much easier to feed the baby. In the 20th month there was much improvement in the tolerance to food consistency, the baby willingly and without particular difficulties ate bits of food the same size as one-half of a rice grain (significant tolerance to lumps in food). The next 6 months of systematic feeding therapy included external therapeutic speech massage of face and internal therapeutic speech massage of oral mucosa and training of chewing.

11 Gross motor skills - motor skills of the entire body which are being acquired by a baby - head control, turning, crawling, walking, climbing stairs, running, cycling.

12 Fine motor skills- motor skills which refer to manipulation movements of hands and fingers, which require proper coordination eye-hand, spatial vision and concentration-such as pincer grasp, using spoon, drinking from a cup, building a brick tower, drawing, cutting paper, buttoning up.

13 Corrected age = birth age 'minus' missing weeks to the birth date. 
In the first assessment of linguistic behaviour - in the fourth month of life - some attempts of cooing are noted, namely ła-ła as well as singing when playing with the caregiver. At the age of 5 months more syllables appeared me-me, ma-ma, gi-gi; melodious singing was still observed as well as throaty sounds. The baby correctly turned towards auditory stimuli and visual stimuli, however, visual autostimulations were observed - hands were brought close to the eyes and moved in a specific way (flutter). Over the age of 7 months more intensive cooing was observed. The baby was able to point out what he wanted to play with. In the 10th month the first vowels appeared $a$, $o$ - sometimes voiced louder, sometimes quieter, as well as more syllables $b u$ - $b u$, lo, $d y$. In the assessment in the 11th month more new sounds were noted: ge, be, ly, ble, gre, de, ag, no, as well as extended time of cooing and repetition of syllable strings. The baby started to imitate an adult person's position of lips. When the baby wanted something, this is communicated by screaming. At the same time the baby was able to continue a syllable dialogue when initiated by an adult. After the age of 13 months cooing was still predominant and more syllables appeared be-be, $d y s-d y s$, pe-pe, aaa as well as singing; lips vibration appeared, as well as imitation of the noises made by the nearest people from his surroundings (and also blowing kisses and fish-gaping). At home the baby uttered additional syllables ba-be, bu, kaj, na. In the 19th month, the elements of verbotonal method ${ }^{14}$ were introduced as further therapy as well as a string of vowels $a-O-u / a-O-u-e)$. The baby, especially when in motion, made sounds and uttered more new syllables (closed syllables), laughed loudly. At home the child 'spoke a lot', tried to pronounce words, repeating some words which he had heard. In the 22 nd month the verbotonal method was replaced by the Knill ${ }^{15}$ method. As soon as the child was 2 years old, the neurological and speech therapy was supplemented by another tool assisting in communication: selecting among concrete items (pictures, showing subsequent activities); the talks were executed during the class; ${ }^{16} 4$ months later basic Makaton ${ }^{17}$ gestures were introduced as a part of the therapy such as jeszcze 'once more', koniec 'end', pomoc 'help', since still there were no single words uttered without assistance. At the age of 2.6 years the boy used words ne-ne 'no', tete, tata, leo, papa, gaga (Aga - his mother's name). With his twin brother he communicated without words. 3 months later more words and syllables appeared - mama 'mum', tata

14 The Verbotonal method involves the stimulation of motoric, auditory and visual perception, sense of balance, concentration and auditory differentiation of sounds: exercises used in this method support the development of speech, improve articulation of phones and sensitize the child's hearing.

15 Knill method - a therapeutic programme directed to a disabled child during which a therapist makes contact with the child when music plays.

16 The pictures show a sequence of tasks which are performed during speech therapy, such as a picture showing a "note" - singing a song, "lips and tongue" - exercises of speech organs, a picture with a "vowel" - articulation exercises, a picture with 'a teddy bear or a doll' - topical play.

17 Makaton - a tool for alternative communication, using gestures for communication, used to facilitate the development of persons with complicated communicative needs. 
'daddy', tu, da, baba, wowo (synonym of his brother's name), hoho, me, dudu 'much'. Also Makaton gestures were used for communication - koniec 'end', jeszcze 'once more'. These were meaningful words in the communication between the therapist and the child. Thanks to these words the therapists decoded the non-verbal message telling whether the therapist could continue with the exercise in question. The child was an active participant of the therapy and could decide about the pace of the exercises and control the intensity of stimuli (especially during sensory desensitization of the face and oral mucosa). Speech therapy was supplemented by auditory exercises (noises made by animals, everyday objects, vehicles), auditory perception exercises, breathing exercises as well as perfecting of the fine motor skills and eye-hand coordination. At the age of 3 the child started to utter more words moto, ciocia 'auntie', kurka 'small hen', nos 'nose', osa 'wasp', jajo 'egg', oko 'eye'.

\subsubsection{Assessment method}

In order to assess the boy's progress in active and passive speech development, the Kielin ${ }^{18}$ scale is used. The following skills are evaluated: visual perception, auditory perception, gross motor skills, fine motor skills, social development, imitation of motions, eye-hand coordination, cognitive functions, self-dependency and understanding and the development of speech. The child was assessed at the age of 2, 3 years and 4 years.

\subsubsection{Results}

The following description presents the results obtained by the boy in the aforementioned time frame for the passive and active speech tasks.

Age 2 years

Assessed tasks in passive speech:

- understanding the command to greet an acquaintance (such as holding out the hand),

- understanding the command daj buzi 'kiss me', with appropriate reaction,

- pointing out where the head, ear, nose, face and hair are,

- understanding of the instruction patrz na mnie 'look at me',

- correctly pointing to the forehead,

- correctly pointing to the fingers,

- correctly pointing to the stomach,

- correctly pointing to the eyes,

18 The Kielin scale - a diagnostic tool to record a student's progress, which evaluates: visual perception, auditory perception, fine and gross motor skills, social development, development of speech (passive and active), imitation and eye-hand coordination. 
- correctly pointing to the legs,

- correctly pointing to one and then the other hand,

- correctly pointing to one and then the other ear,

- correctly pointing to a pocket in clothing,

- correctly pointing to a shirt,

- correctly pointing to buttons in clothing,

- correctly pointing to a hat,

- correctly pointing to one shoe and then the other,

- understanding the command podaj bucik 'give me the shoe',

- understanding the command poszukaj lalke 'find the doll',

- understanding the command wytrzyj swój nos chusteczka 'wipe your nose with a handkerchief',

- understanding the command uściskaj swoja mamę 'hug your mummy',

- proper understanding of a two-part command with a proper reaction (such as Zamknij drzwi i umyj rece 'Close the door and wash your hands', Podnieś ręke do góry i otwórz usta 'Raise your hand and open your month').

The child executes all the tasks unassisted, with the exception of the last one; the last one - with assistance from the testing person. The result is $100 \%$ of the developmental standard (including 4\% with the assistance of the therapist).

Assessed tasks in active speech:

- ability to utter 5 words,

- ability to utter a word consisting of three vowels,

- ability to use autonomous child speech,

- ability to connect the words and gestures in social interactions,

- naming familiar things and persons,

- connecting words freely,

- ability to answer the question Jak się nazywasz? 'What is your name?',

- using approximately 20 words,

- naming familiar toys,

- ability to name several types of food (such as bread, cake, juice etc.),

- asking question using proper intonation,

- ability to verbally answer the question Czego chcesz? 'What do you want?'

The boy showed no ability to use autonomous child speech; nor was he able to connect the words and gestures in social interactions. When assisted by the therapist, he performed the command to ask questions using appropriate intonation. The boy realized the other tasks unassisted. The result was $75 \%$ of the developmental standard.

Age 3 years

Assessed tasks in passive speech:

- understanding of personal pronouns, correct reactions to instructions (such as daj to jej 'give it to her'), 
- understanding of the following sentence, pointing out to proper items among many possible: pokaż, na czym kroi się chleb 'show me what do you cut the bread with', pokaz, co wkladamy na nogi 'show me what do you put on your feet', czym się rysuje 'what do you draw with?',

- proper reaction to the following commands: wtóz tyżeczkę do kubka 'put the spoon in the cup', potóz klocek na talerzu 'put the brick on the plate', posadź misia na krześle 'seat the teddy bear on a chair',

- understanding the words: mało 'little', dużo 'much', mały 'small, duży 'big', jeden 'one', daleko 'far', blisko 'near' - correct indication on items or pictures,

- ability to show mokre 'wet' and suche 'dry' items,

- understanding the words 'eating' and 'drinking' with correct allocation of pictures or indication of items.

The boy performed all the tasks correctly and unassisted. The result was $100 \%$ of the developmental standard.

Assessed tasks in active speech:

- ability to repeat, after an adult, two numbers or two words in the same order,

- ability to verbally indicate physiological needs (such as the lavatory),

- using the word 'please' in an appropriate moment when an adult reminds him of it,

- naming 5 various pieces of clothing,

- counting to 10 ,

- ability to imitate the noises made by familiar toys or objects Jak warczy ten samochód? 'How is this car whirring?', Jak uderza ten mlotek? 'How is this hammer striking?',

- ability to express a request using the word chce 'I want', connecting it with another word (such as Chce pić 'I want a drink.'),

- ability to answer the question gdzie...? 'where....?' using a prepositional phrase ( $w$ kubku 'in the cup', pod stotem 'under the table', na stole 'on the table'),

- ability to connect two words in order to specify the possessive state (such as samochód taty 'daddy's car', buty mamy 'mummy's shoes'),

- using at least 10 words specifying items or places not in home,

- ability to correctly repeat, after an adult, the consonants: $p, b, m, n, w, h$,

- correct specification of his age - verbally or by raising a correct number of fingers,

- using the word kciuk 'thumb' and pointing it among his fingers on both hands,

- ability to imitate noises made by at least 5 familiar animals,

- starting to use the plural form (such as pitki 'balls', lalki 'dolls'),

- ability to use the verb jest/być "to be" in affirmative sentences (such as Mama jest $w$ domu? 'Mum is at home'?), 
- ability to ask questions starting from the word co...? 'what...', gdzie...? 'where...?' (open questions),

- ability to repeat, after an adult, an utterance partly in a quiet voice and partly in a loud voice,

- ability to describe a picture using a four-word sentence containing a noun and a verb,

- using the pronouns ja 'I', mi/mnie 'me', moje 'my' instead of his own name,

- ability to correctly repeat, after an adult, the consonants: $k, g, t, d$,

- ability to answer to a question Kto...? 'Who...?' by naming other persons and the relationship (such as ciocia Ola 'auntie Ola') or the word Pan 'Mr' (such as Pan Jacek 'Mr Jacek'),

- use of possessive forms of nouns (such as szal tatusia 'daddy's scarf', pitka Kasi 'Kate's ball'),

- knowledge and ability of showing the words: łokieć 'elbow', dton' 'hand', ramię 'arm', kolano 'knee' and ability to point concrete body parts,

- knowledge and ability of showing the words: czubek głowy 'top of the head', podeszwa stopy 'sole of the foot', boki ciała 'sides of the body', przód i tyl ciata 'front and back of the body' and ability to point concrete body parts,

- ability to use the names of the following classes of objects - animals (To sq zwierzęta 'These are animals' when pointing at for example dogs and cats), toys and food.

The boy correctly performed 13 tasks without assistance. 3 tasks which involve showing on himself parts of body are performed only partially (the child did not point to all of the mentioned parts). The same situation happened when the task involved the ability to answer the questions about relatives. The boy performed the tasks involving counting to 10 from memory and connecting two words regarding possessive state with assistance. The boy needed assistance with the command to imitate the noises made by at least 5 animals that he was familiar with and with making the questions starting with co...? 'what...?' and gdzie...? 'where?'. He failed to execute the tasks with the expression chce 'I want', failed to answer the questions gdzie...? 'where...?' by using a prepositional phrase, did not use plural form; nor did he use the verb 'to be' in affirmative sentences. The boy was not able to describe a picture using a four-word sentence including a noun and a verb, did not use pronouns ja 'I', mi/mnie 'me', mój 'my', possessive forms; nor did he use the elements of the class of objects: animals, toys and food. The result was $65 \%$ (including tasks executed without assistance $50 \%$, with assistance $-15 \%$ ).

Age 4 years

Assessed tasks in passive speech:

- understanding of the word zero 'zero', when commanded podaj zero klocków 'give me zero bricks'- no bricks are given, 
- understanding of the words: nad 'above', pod 'under', przed 'in front', $z a$ 'behind', $z$ dala od 'far away from' - correct showing or executing the instruction,

- understanding of the words: przed i za 'before' and 'after' - correct showing or executing the instruction,

- understanding of the words: $z$ dala od 'far away from' - correct showing or executing the instruction,

- understanding of the words: więcej 'more', mniej 'less' - correctly showing the bricks which have been named like that,

- understanding of the words: największy 'the largest', najmniejszy 'the smallest' correctly showing the bricks in such a way,

- understanding of the term: najkrótszy 'the shortest', najdluższy 'the longest' correctly showing the bricks in such a way,

- understanding of the term: najniższy 'the lowest', najwyższy 'the tallest' - correctly showing the bricks in such a way,

- understanding of all of the following words, pointing to correct pictures: gruszka 'pear', jabtko 'apple', bocian 'stork', kura 'hen', kogut 'rooster', sowa 'owl', ogon ptaka 'bird's tail', dziób 'beak', pazur 'claw', koń 'horse', stoń 'elephant', zajac 'hare', lis 'fox',

- understanding of all of the following words, pointing to correct pictures: lekarz 'doctor', nauczycielka 'teacher', kucharz 'cook', lotnik 'pilot', kierowca 'driver',

- ability to show the following colours: czerwony 'red', zielony 'green', niebieski 'blue', żółty 'yellow', biaty 'white', czarny 'black',

- understanding of the names of the following geometric figures and ability to point them: kwadrat 'square', trójkąt 'triangle', prostokat 'rectangle', koło 'circle',

- understanding of the words: szybki 'fast', wolny 'slow', correctly pointing to pictures,

- understanding of the words: ciężki 'heavy', lekki 'light' correctly pointing to pictures.

Given 14 tasks, the boy executed correctly and in full only two, regarding the colours and geometric recognition, were fully completed. He was able to partially point pictures, such as jabłko 'apple', gruszka 'pear', kon 'horse', zając 'hare', lis 'fox', stoń 'elephant', however, in order to consider this task as correctly performed, all of the pictures must be named and indicated. Result was $14 \%$.

Assessed tasks in active speech:

- ability to use word dziękuje 'thank you' when reminded by an adult,

- knowing the names of at least 4 peers,

- ability to use the demonstratives: ten 'this', tamten 'that', $c i$ 'these', tamci 'those',

- use of adverbs: szybko 'fast', wolno 'slowly', teraz 'now',

- ability to ask a closed question, 
- in response to question: Jakie to jest? 'How is it?' the ability to use words: duże 'large' and mate 'small',

- answer to the question about the boy's full name (first name and surname),

- use of personal pronoun: on 'he', ona 'she',

- ability to answer questions such as: którędy...? 'which way...?', jak 'how', jaka droga...? 'what way...?',

- ability to repeat, after an adult, in the same order a string of three numbers or words,

- use the words: ładny 'pretty', lepki 'sticky' and gładki 'smooth' when describing items,

- ability to express an activity in the past tense,

- ability to describe recent events,

- ability to memorize a short (4-6 words) message and verbal transmittal of this message to another person after a while,

- ability to imitate, after an adult, the way of speaking in low and high tones and speaking fast and slowly,

- expressing an activity in the future tense,

- proper answer to the question: $Z$ czego jest to zrobione? 'What is it made of?', when showing szklanka 'a glass' (glass), nóż 'a knife' (metal, iron, steel), krzesło 'a chair' (wood), ubranie 'clothing' (fabric, wool, cotton, linen).

Among 17 tasks, the boy completed 4 without assistance and one with assistance. He had no difficulties in performing the task involving the use of the word dziękuje 'thank you', knowing the names of at least 4 peers and his own first name/surname. With great difficulty, but unassisted, the boy memorized and repeated a short message. He needed some assistance with the task which involved the answer to the question Jakie to jest...? 'How is it ...?' (small, large). The boy was not able to execute correctly any of the other instructions. The result was $29 \%$ (including unassisted work $-23 \%$, assisted $-6 \%$ ).

The last speech therapy assessment at the age of 4.4 years indicated continuous and dynamic increase of the boy's vocabulary. The grammatical forms which were used are the sentence words (elliptical clauses), simple sentences. The boy less and less frequently used screams, from time to time there are squeals (very high pitch screams). He answered simple questions, names items, pictures, asks for help.

\subsection{Twin 2}

\subsubsection{Case description}

The other boy was born in $29 \mathrm{Hbd}$, with birth weight $960 \mathrm{~g}$ (birth weight greater than that of his brother by 360g), also scored 6 in Apgar scale. In the first 24 hours the baby 
suffered from a brain haemorrhage (without symptoms of anoxia, as was in the case of the first baby); the baby spent 1.5 months in a neonatal incubator. The baby was fed through a tube for one month. Attempts to breastfeed were unsuccessful; the baby was fed from a feeding bottle with a teat - a standard teat, not a special teat as in the case of his brother. Hearing test revealed no abnormalities.

The first assessment in terms of neurology and speech therapy took place after 7 months (the corrected age -4 months). The test for food intake competences determined that the baby - similarly as in the case of his brother - accepted a touch on his face; sensory feelings were at the correct level of tolerance. Occasionally the baby choked on his food or saliva, which could indicate incomplete coordination suckingbreathing-swallowing, or may point out to reduced muscular tension in articulation organs. The baby started to take food other than liquid three months earlier than the first baby - in his seventh month. In contrast to his brother, the baby tolerated lumpy food. As regards the feeding function development, new meals with various textures were introduced (bread, rice, corn, carrot).

In the assessment of linguistic behaviour the beginning of babbling was noted melodious, correct when uttered, the stage of cooing $\mathrm{mmmm}$ as well as social laughter, which appeared earlier than in the case of his brother. The boy correctly reacted to sounds, turned his head towards an auditory stimulus. At the age of 5 months some sounds appeared $a a, h a, h o, a-b i, a-b i$, dynamic vibration of lips and loud screams. Two months later the first "dialogue" with his parents was observed, and intensified babbling. In his 10th month of life the boy uttered melodious vowels aaa, eee, could repeat sounds uttered by himself. He initiated contacts with the persons nearby ('dialogue' by babbling); replied with a smile on his face. Neurological and speech assessment in 12th month registered the first words: dada, baba, mama, tete, gaga, dede - active verbal communication; the boy willingly interacted socially, demanded attention and 'dialogue'). Due to the fact that there were no grounds for starting speech therapy, the next diagnostics took place after 1,5 years, when the boy was 2.5 years old. The boy spoke a lot, using his own "language". He used the elements of the linguistic code: mama 'mummy', tata 'daddy', nie 'no', siedz' 'sit' when he wanted to get something. He was able to imitate the noises made by animals which he heard: cat (miaow), pig (oink-oink), cow (mooo). He understood simple commands, such as włącz 'turn it on', zrób 'make', cześć 'hello', chodź 'come', idź 'go', napij się 'drink', jaki jesteś duży? 'how tall are you?'. Because of a rather small lexicon and no acquisition of vocabulary, the boy started speech therapy and psychological therapy. The Knill method was introduced, elements of verbotonal method, chewing training, sound imitation exercises, breathing exercises and exercising to improve the articulators. As a part of psychological therapy multisensory stimulation started (sonic, auditory, tactual), exercises of fine motor skills - hand therapy (play involving manipulation, such as using Play-Doh, kinetic sand), some exercises shaping and 
perfecting the eye-hand coordination (such as building a tower, pyramid, domino), situation and relationship exercises as well as the Tomatis auditory training. ${ }^{19}$ At the age of 4, the speech therapy was supplemented by standard articulation exercises, verticalization of the tongue - due to reduced muscular capacity of lips and tongue. At the age of 4.4 years the boy demonstrated rich vocabulary pertaining to familiar situations. The sentences used by the boy were simple and compound ones, and the reception of verbal messages was adequate to the age range. Not all the phones and inflexion suffixes were properly performed.

\subsubsection{Assessment method}

The Kielin scale was also used to assess the boy's achievement in the development of passive and active speech. Due to the fact that in the scope of speech development the boy started speech therapy later than his brother, the diagnostic assessment was made only once, when he was 4 years old (test diagram see section 2.1.3 of this paper).

\subsubsection{Results}

Similarly as in the case of the first twin, the description presents the boy's achievements regarding the task in passive and active speech.

In the test of passive speech, the boy correctly completed 10 tasks out of 14 . The boy three tasks were completed with assistance, involving the ability to understand the words nad 'above', pod 'under', przed 'before', za 'behind', z dala od 'far away from' and przed/za 'in front/behind'. The boy was not able understand the word 'zero' and did not understood the command daj zero klocków 'give me zero bricks'. The result was $92 \%$ (including the tasks completed without assistance $-71 \%$, with assistance $-21 \%$ ).

The boy correctly performed 12 out of 17 commands regarding active speech. With the assistance from the therapist - 4 tasks, regarding the use of pronouns (ten 'this', tamten 'that', $\mathrm{ci}$ 'these', tamci 'those'), regarding the answer to questions such as którędy...? 'which way...?', jak...? 'how...?', jaka droga...? 'what way...?', and the ability to imitate, after an adult, the way of speaking in low and high tones and speaking fast and slowly. The boy answered the questions $Z$ czego jest zrobione? 'What is it made of?' (a glass, a knife, a chair, clothing) with assistance. The result was $88 \%$ (including the tasks executed without assistance $-70 \%$, with assistance $-18 \%$ ).

The last speech therapy assessment carried out at the age of 4.4 years showed that the boy communicated verbally using simple and compound sentences. Recommen-

19 The Tomatis method - auditory stimulation program (auditory training) used in the situation of auditory memory disorder and communication disorders in children and adults. 
dations for further therapy were the improvement of articulators, improvement of auditory and visual perception, improvement of vocabulary, development of logical thinking, as well as the extension of knowledge regarding spatial terms, encouragement to ask questions (conducting a dialogue, discussion), learning the description of items using adjectives as well as attempts to talk about past events in the form of short utterances.

Comparison of the speech development level of the twins at the age of 4 .

A comparison of the results in the following table (Tab. 1) shows high advantage of one of the twins (second twin described in this paper), in terms of the development of both passive speech and active speech.

Table 1. Results regarding the speech development for the twins at the age of 4

\begin{tabular}{|c|c|c|c|}
\hline \multicolumn{2}{|c|}{ Twin 1 } & \multicolumn{2}{c|}{ Twin 2 } \\
\hline Passive speech & Active speech & Passive speech & Active speech \\
\hline 14 & 29 & 92 & 88 \\
\hline
\end{tabular}

As can be seen the difference is significant. The second twin shows achievements close to the developmental standard. The first twin shows clear deficits. The root cause of this difference is most probably perinatal issues, related to lower birth weight and anoxia as a result of brain haemorrhage. Also in the motor skill development there are noticeable disproportions between the twins. The boy also with anoxia requires more care from his parents in terms of daily care activities, attention and assistance in overcoming architectural barriers. The child stumbles frequently and has reduced movement coordination and balance.

\section{CONCLUSIONS}

The brothers are under constant care of a speech therapist and a psychologist. In spontaneous speech there are distinct differences in communicative competences. The boy born with lower birth weight, who spent more time in the neonatal incubator and started his speech therapy earlier due to much reduced tolerance to food intake has smaller vocabulary than his brother. In interaction with his peers, the boy is withdrawn and still uses screams to express his disapproval in conflict situations. In interaction with adults, the boy willingly starts a dialogue, nevertheless it is rather simple and the adult must to support the conversation. In the case of the second boy, the etiological factor in the speech development delay is most probably the reduced efficiency of the speech organs (such as reduced muscular tension of lips and tongue, the lack of tongue verticulization, reduced vertical tension of the body). His vocabulary is richer, he uses longer utterances than his brother and more eagerly initiates 
dialogue with his peers. The speech therapy is based mostly on the improvement of articulation of phones and improvement of speech clarity. Both boys remain under the care of the early intervention centre to mitigate the current deficiencies in terms of speech development and interpersonal communication.

\section{References}

Cieszyńska, Jagoda, Marta Korendo. Wczesna interwencja terapeutyczna. Kraków: Wydawnictwo Edukacyjne, 2007.

Czaplewska, Ewa. „Diagnoza zaburzeń rozwoju artykulacji”. In: Diagnoza logopedyczna, eds. Ewa Czaplewska, Stanisław Milewski, 65-120. Gdańsk: Gdańskie Wydawnictwo Psychologiczne, 2012.

Demel, Genowefa. Minimum logopedyczne nauczyciela przedszkola. Warszawa: Wydawnictwo Szkolne i Pedagogiczne, 1987.

Kaczmarek, Leon. Nasze dziecko uczy się mowy. Lublin: Wydawnictwo Lubelskie, 1977.

Kielar-Turska, Maria. „Rozwój sprawności językowych i komunikacyjnych”. In: Diagnoza logopedyczna, eds. Ewa Czaplewska, Stanisław Milewski, 15-64. Gdańsk: Gdańskie Wydawnictwo Psychologiczne, 2012.

Stecko, Elżbieta. Zaburzenia mowy dzieci - wczesne rozpoznawanie i postepowanie logopedyczne. Warszawa: Wydawnictwa Uniwersytetu Warszawskiego, 1996.

Abstract

The proper forming of speech behaviour depends on the pre-natal and post-natal development optimum the brain structure and potential social and cultural factors affecting language acquisition in children. Any anomalies and disorders related to perinatal period may significantly affect any abnormal speech development and delayed speech development. Pre-term birth and extreme prematurity predisposes to developmental disorders connected with the shaping of communicative and linguistic competency in later years. The example of a pair of prematurely born twins highlights the impact of the perinatal period on the delayed speed development and the impact of extremely low birth weight and damage to cortex structure on the differences between the qualitative and quantitative language acquisition parameters of the brothers. The first symptoms of neurodevelopmental disorders are manifested as difficulties in food ingestion, execution of motoric movement of tongue, lips and jaw, as well as sensory reception of stimuli coming from the consistency of ingested food. The primary and pre-lingual skills predict the quality of children's linguistic behaviour. Neurological speech and language therapy started at an early age is able to mitigate the consequences of neurological damage and results in the improvement of development in terms of speech.

Keywords: linguistic competence, communicative competence, orofacial reflex reactions 


\title{
KSZTAŁTOWANIE SIĘ KOMPETENCJI JĘZYKOWEJ I KOMUNIKACYJNEJ BLIŹNIĄT Z OPÓŹNIONYM ROZWOJEM MOWY W WIEKU 0-4 LAT
}

\begin{abstract}
Abstrakt
Prawidłowe kształtowanie się zachowań językowych uzależnione jest od optymalnego rozwoju struktur mózgowych okresu prenatalnego i postnatalnego oraz potencjalnych czynników społeczno-kulturowych, wpływających na akwizycję języka u dziecka. Wszelkie anomalie i zaburzenia związane $\mathrm{z}$ okresem okołoporodowym mogą mieć znamienny wpływ na dysharmonie rozwoju mowy oraz opóźnienia rozwoju mowy. Przedwczesny poród oraz skrajne wcześniactwo predysponują do występowania zaburzeń rozwojowych w obrębie kształtowania się kompetencji komunikacyjnych oraz językowych w kolejnych latach. Przykład bliźniąt urodzonych przed czasem ukazuje aspekt wpływu okresu okołoporodowego na opóźnienie rozwoju mowy oraz wpływu ekstremalnie niskiej urodzeniowej masy ciała i uszkodzeń struktur kory mózgowej na różnice pomiędzy parametrami ilościowymi i jakościowymi nabywania języka między braćmi. Pierwsze symptomy zaburzeń neurorozwojowych demonstrują się w trudnościach poboru pokarmu, realizacji ruchów motorycznych języka, warg oraz żuchwy, a także odbioru sensorycznego bodźców płynących z konsystencji przyjmowanych pokarmów. Umiejętności prymarne (pierwotne) i prelingwalne prognozują jakość zachowań językowych dziecka. Wcześnie podjęta terapia neurologopedyczna jest w stanie zminimalizować skutki uszkodzeń neurologicznych oraz wpłynąć na poprawę ścieżki rozwojowej dotyczącej rozwoju mowy.
\end{abstract}

Słowa kluczowe: kompetencja językowa, kompetencja komunikacyjna, odruchowe reakcje orofacjalne 